\title{
Les jaugeages dans les ouvrages et les centrales hydroélectriques
}

\author{
(Résumé historique)
}

\author{
par la Prof. Sthponas KOLUPAILA. \\ NOTHE DAME (NDIANA), U.S.A.
}

\section{Water measurements in hydraulic structures and power plants}

(Historical sketch)

\author{
ny Prof. Stmponas KOLUPATLA. \\ NOTRE DAME (INDHANA), U.S.A.
}

\begin{abstract}
Ce mémoire présente nne revue du développement de la technique des jaugeages en milienx artificiels.

La mahode volumétrique, l'écoulement par orifices et déversoirs, les tuyères et modules, l'ecran hydrometrique, les jaugeages par tubes de pitot ef pas moulinets dans les canaux decowberts ef dans les conduites forées, les méthodes d'Allen et de Gibson, les méthodes chimiques el électriques, ainsi que d'autres, sont présentés.

La mention de quelques essais comparatifs termine le mémoire.
\end{abstract}

Les mesures hydrauliques sont aussi anciennes que l'hydraulique mềme. On ne peut guère s'imaginer que les exploitants des anciens réseaux d'irrigation en Egypte, Mésopotamie et en Asie centrale aient pu assurer une juste répartition des eaux parmi les irrigants, sans avoir recours à des appareils de jaugeage quelconques. Frontin (Sextus Julius Frontinus), curateur des eaux à Rome à la fin du premier siècle de notre ère, nous a laissé une description de la méthode de mesure employée à l'époque, méthode utilisant des buses et négligeant la vitesse et la pression. L'évolution des techniques de jaugeage a suivi le progrès de la technique en général, surtout pendant les cent dernières années. De très nombreuses idées ont été adoptées et exploitées dans ce domaine.

\begin{abstract}
Paper presents a short review of the development of hydrometric technique in artificial conditions.

Volumetric measurements, orifices, weirs, throats and fumes, hydrometric screen, pitot tubes and current meters, in open ohannels and in penstocks, saltwelocity, dilution, impact, ultrasonti maqnetic, thernodpramic and other methods are mentioned.
\end{abstract}

Some comparative tests are listed.

Water measurement is as old as is the hydrauhe engineering. The old irrigation systems of Egypt, Mesopotamia, Central Asia, must have used certain devices for a just water distribution among the customers. Sextus Julius Frontinus, the water commissioner in Rome at the end of the first century A.D., described the water measuring of those times through nozzles disregarding velocity and pressure. Development of water measurement technique followed the progress of engineering, particularly during the last 100 years. Very many ideas were adopted and put into practice in this field.

An attempt is made here to show the variely of hydrometric methods and instruments as 
L'auteur essaie de mettre en évidence la grande diversité des méthodes hydrométriques et des appareils utilisés dans les milieux «artificiels » des barrages, canaux, centrales hydroélectriques et des laboratoires d'hydraulique.

\section{MESURES VOLUMETRIQUES}

La méthode volumétrique de mesure des débits est la plus précise de toutes. Son seul inconvénient pourrait résider en la nécessité de prévoir un très grand réservoir. Le réservoir construit pour le jaugeage du débit en aval du barrage d'Assouan, en Egypte, est le plus grand que l'on connaisse. Construit en 1912, il présenlait une surface de $70 \times 72 \mathrm{~m}$, une profondeur de 5 mètres, soit un volume utile de $22000 \mathrm{~m}^{3}$.

Les réservoirs d'accumulation, les écluses, des canaux amont et de fuite cloisonnés, ont lous été utilisés comme réservoirs pour les essais de turbines et de déversoirs. Les faibles débits, tels que débits de fuite des vannes et des robinets, sont normalement mesurés à l'aide de capacités jaugées portatives.

Tous les laboratoires d'hydraulique se servent de la méthode volumétrique comme étant la plus sûre, soit en mesurant les varialions de niveau dans un réservoir, soit en pesant le débit sortant au moyen d'une balance. Le laboratoire à ciel ouvert de Walchensee, en Bavière, comporte un lac constituant un réservoir volumétrique de $1600 \mathrm{~m}^{3}$.

\section{ORIFICES}

La mesure des débits se fait très facilement en faisant passer l'eau par un orifice; il suffit alors de mesurer seulement la hauteur d'eau. De nombreux dispositifs anciens étaient basés sur l'écoulement de l'eau à travers un ou plusieurs orifices ou fentes, dans des conditions d'approche en amont données; tels sont les modules utilisés dans les réseaux d'irrigation, le «pouce d'eau », le «pouce du mineur $»$, la jauge de Max Clark, le pouce normalisé de l'Elat du Colorado, le «pouce du constructeur de moulins», le calice romain. Des dispositifs ingénieux el admirés par tous, dénommés «châteaux d'eau » (castellum acqua, Wasserchloss, Wasserlunst) furent mis au point par S.J. Frontin en l'an 97, M. Mersenne en 1644, E. Mariotte en 1686, M. Bion en 1709, J. Leupold en 1724, J.-V. Poncelet en 1832 , K.R. Bornemann en 1849, H. Mangon en 1863 , et K.M. Ignatov en 1914.

Une «danaïde» fut mise an point par $E$. Brauer en 1892, sous forme d'un \& tonneau sans fond» comportant une série d'orifices alignés applied in artificial condilions of dams, canals, power plants, and hydraulic laboratories.

\section{VOLUMETRIC MEASUREMENTS}

The volumetric method of discharge measurement is the most correct. The only objeclion could be the size of the container. The largest known container for calibration of a dam outlet was built in 1912 below the Asswan Dam in Egypt. It had an area of $230 \times 236$ feet, a depth of 17 feet, a working rolume of 776,000 cuhic feet.

Storage reservoirs, ship locks, bulkheaded forebays and tailraces, somelimes penstocks were used as containers for turbine and spillway tests. Small discharges, like leakage through gates and valves, are usually measured by portable volumetric tanks.

Every hydraulic laboralory uses the most reliable volumetric method, eilher by level difference in a tank, or by weighing outlow on seales. The Walchensee open-air laboralory in Bavaria has a volumetric pond of 56,500 cubic feet volume.

\section{ORIFICES}

Flow measurement is very convenient when water is compelled to pass through an orifice and head of water is to be observed only. Many old devices were based on water flow through one or more orifices or slots under certain approach conditions: irrigation modulus, water inch, miner's inch, the Max Clark's gauge, Colorado State inch, millwright inch, Roman calix. S.J. Frontinus in 97, M. Mersenne in 1644, E. Ma riotte in $1686, \mathrm{~N}$. Bion in $1709, \pi$. Leupold in 1724, J.V. Poncelet in 1832, K.R. Bornemann in 1849 , H. Mangon in 1863, K.M. Ignatov in 1914, designed ingenious devices, admired by peojle as water caslles (castellum aquae, Wasserchloss, Wasserkunst).

In 1892, E. Brauer introduced a danaide, a "boltomless barrel", with series of orifices in a row, to use for measurement of large flows. Such an installation was used about 1900 in France for water wheel lests: "The discharge is passed into a large funnel shape vessel the upper part of which is cylindrical and pierced with 80 rectangular openings disposed around the periphery. The water flows out of the openings, 80 in all, and one of these streams is passed through a water meter as a measure of the total volume" . 
sur un rang, pour la mesure des grands débits. Une lelle installation fut employée en France vers 1900 pour des essais sur des rones hydrauliques: «On fait passer le débit dans un grand récipient en lorme d'entonnoir, dont la partie supericure, cylindrigme, est percée de 80 trous rectanguhires disposćs autour de la périphélie. L'eau s'échappe par ces 80 ouvertures, et l'on fail passer l'un de ces jets par un compleur d'eau afin de pouvoir déterminer le volume total $\%\left({ }^{*}\right)$

Le même principe est parfois employé pour le jangeage des dobits en riviere. Les vannes du barrage d'Assisuan servent depuis 1912 pour la mesure dos débits sortant du barrage. Celui-ci comporle 180 orifices roctangulaires, larges de $2,0 \mathrm{~m}$ el hauts de 3,50 et de $7 \mathrm{~m}$.

\section{DEVERSOIRS}

La mesure des débits s'éconlanl par un dérersoir est encore plus pratique et plus sûre. Le

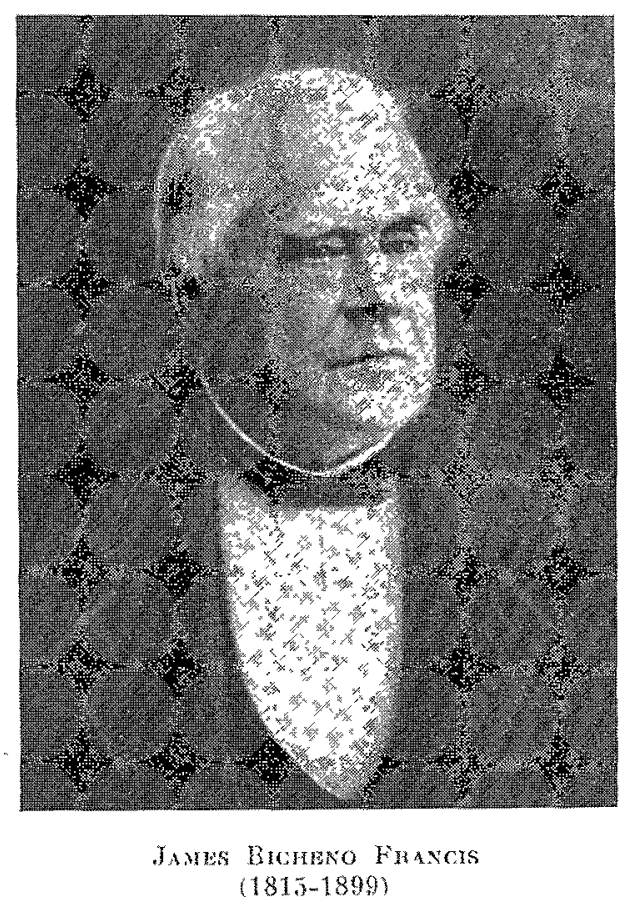

marguis G. Poleni fut le premier a ntiliser un deversoir en 1717, suivi par P.L.G. du Bual en 1779, el par $J$. Weisbach en 1841. Linventeur d'une turbine à rćaction, J.-B. Francis, établit le premier laboraloire d'essais hydrauliques sur des Unrbines, à Lowell, dans l'Etal de Massachusetts. Un déversoir rectangulaire, d'une longueur de $4,26 \mathrm{~m}, \mathrm{y}$ ful installé cl étudié en 1852

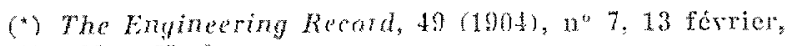
p. $187, \mathrm{Ne}$ jork.
Sometimes this principle is applied for river discharge measurement. Sluice gates in the Asswan Dam are used for oulflow measurement since 1912. There are 180 rectangular orifices in the dam, 6.5 reet wide, 11.5 and 23 feet high.

\section{WEIRS}

Measurement of overflow over a weir is still more convenient and reliable. Marquis $\mathrm{G}$. Polen was the first man to apply a weir in 1717 , P.L.G. du Buat followed in 1779 , J. Weisbach in 1841. J.B. Francis, inventor of a reaction turbine, established the first hydraulic laborntory for turbine tesling in Lowell, Massachusetts, In 1852 a rectangular weir, 14 feet long, was installed and investigaled, a simple formula derived. A classim al work "Lowell Hydraulic Experiments" by Francis was published in 1855 and five editions were issued through 1909.

Rectangular weirs were investigated by H.E.

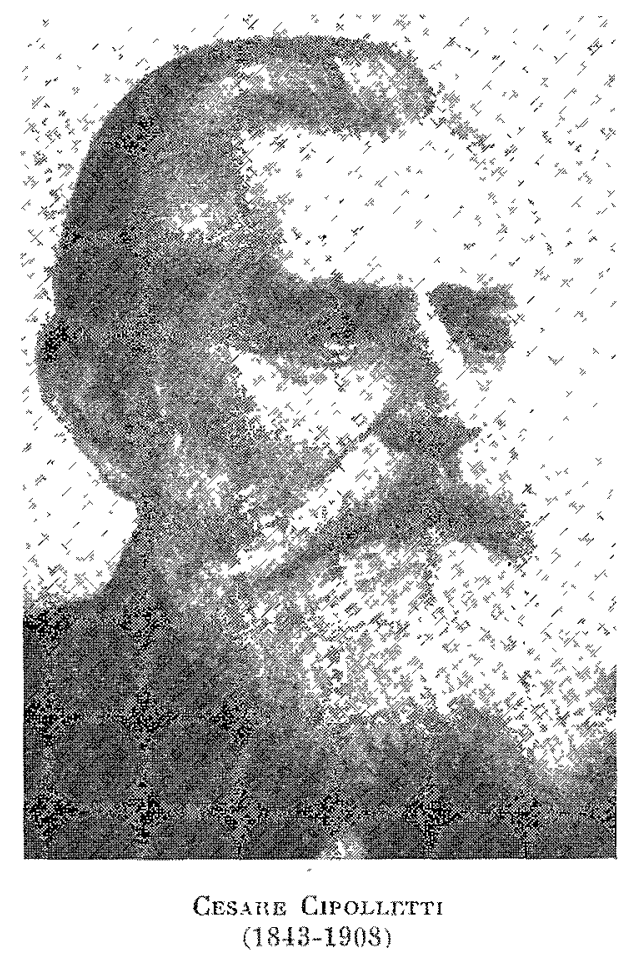

Bazin in 1888-1896, V.W. Hansen in 1892, F. Frese in 1890, K. Kinzer in 1897, Th. Rehbock in 1909-1929, R.R. Lyman in 1912, F.A. Nagler in 1917, V.M. Hégly in 1921, R. Dubs in 1924 , E.W. Schoder and K.B. Turner in 1927, Ch. Keutner in 1929. Some other forms of weir notches were tried and applied. A triangular weir, distinguished by perfect similarity, was invented by

(*) The Engneering Record, 49 (1904), No. 7, Feb. 13, p 187, New Jork. 
et une formule simple put en être dégacée L'ourre classique \&Lwell Hydraulic Experiments $\gg$ (Etudes hydrauliques effectues à Lowell, par Francis, parul en 1855 , el cinq éditions en furent publiées pendant la période $1855-1909$.

H.-E. Bazin éludia les déversoirs reclangulaires en 1888-1896, de même V.W. Hansen on 1892, F. Frese en 1890, K. Kinzer en 1897, Th. Rehbock en 1909-1929, R.R. Lyman en 1912 , F.A. Nagler en 1917, V.M. Hégly en 1921, R. Dubs en 1924, E.W. Schoder et K.B. Turner en 1927, et Ch. Keutner en 1929. Des déversoirs de formes différentes furent également étudiés el utilisés, notamment un déversoir triangulaire permettanl une similitude parfaite, qui fut inventé par J. Thomson en 1858 et éludié par J. Barr en 1910, D.H. Yarnall en 1912-1926, F.W. Greve en 1930, et A.T. Lenz en 1941. En 1870, Cipolletti inventa un déversoir trapézoidal, avec un coefficient de débit compensé pour les contractions latérales; ce dispositif fut étudié par la suite par W.G. Steward et J.S. Longwell en 1911, et par V.M. Cone en 1916. P.W Greve étudia un déversoir parabolique à loi quadralique en 1921, et un déversoir hyperbolique (déversoir proportionnel) à loi linéaire fut inventé par O.V.P. Stout en 1896, modifié par H.H. Sulro en 1908, et étudié par E.W. Rettger en 1914, E.A. Pratt en 1914, M. Rother en 1921, H. Janert en 1930 , et $G$. di Ricco en 1940. Un déversoir circulaire fut étudié par V.M. Cone en 1913, J.L.W. Lillja en 1920, P.W. Greve en 1921-1928, et défini théoriquement par A. Staus en 1926.

Les déversoirs sont généralement utilisés pour le jaugeage des débits dans les petits canaux d'irrigation et de drainage. On installe également des déversoirs fixes dans des petits cours d'eau, ainsí que pour la régularisation des rivières caractérisées par des changements de lit. Les déversoirs de crue des barrages existants sonl également utilisés pour le jaugeage des débits déversés. Le barrage de Keokuk, sur le Mississippi comporte 119 déversoirs, d'une largeur unitaire de $9,15 \mathrm{~m}$, sous une charge de $3,35 \mathrm{~m}$. F.A. Nagler et A. Davis effectuèrent des essais sur l'une de ces sections en 1924, à l'aide de moulinets hydrométriques; la meme section fut également vérifiée sur un modele réduit an laboratoire d'hydraulique de l'lowa. Le déversoir des crues du barrage Wilson, sur le lleuve Tennessee, fut étudié de la même facon par L.G. Puls en 1928.

Les déversoirs ont également été utilisés pour les essais des turbines, étant alors provisoirement aménagés dans un des canaux de tuile. Certains de ces déversoirs étaient de taille assez importante el relativement coûteux. Un déver-
J. Thomson in 1858 and inveshigated by $\int$. Barr in 1910, D.R. Yamall in 1912-1926, F.W. Greve in 1930, A.T. Lenz in 1941. A trapezoidal weiv with a discharge coefleient compensaled for side contractions was invented by $\mathrm{C}$. Cipollolli in 1870, investigaled by W.G. Steward and J.S. Longwell in 1911, Y.M. Cone in 1916. A parabolic nolch with second power formula was lested by F.W. Greve in 1921. A hyperbolic notch or proportional weir with first power for mula was invented by O.V.P. Stout in 1890 , modified by H.H. Sutro in 1908, investigaled by E.IT. Rellger in 1914, E.A. Pratl in 1914, M. Rother in 1921, H. Janert in 1930, G. di Riceo in 1940. A circular weir was investigated by Y.M. Cone, in 1915, J.L.W. Lillja in 1920, F.W. Greve

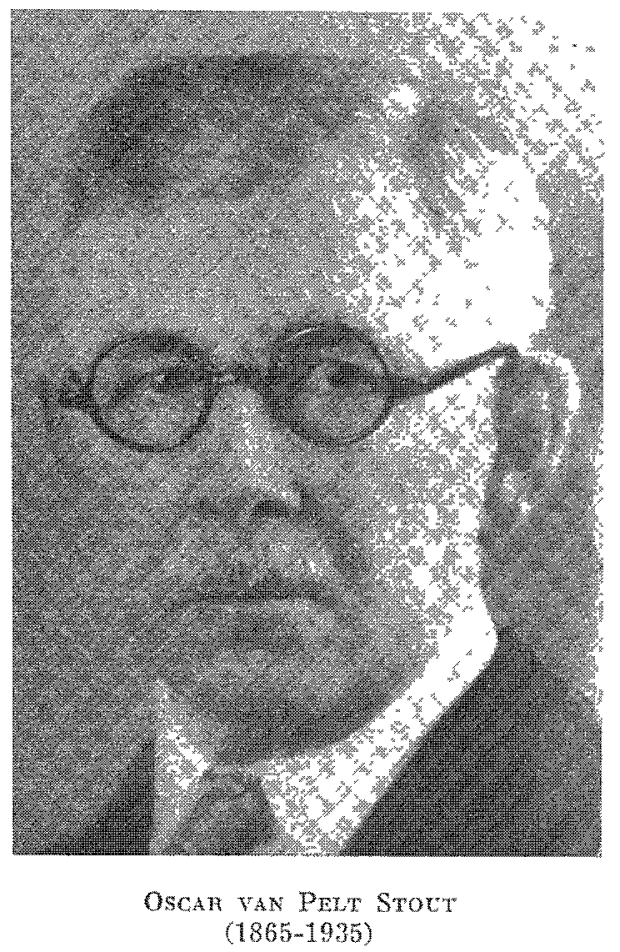

in 1921-1928, theoretically defined by A. Stuus in 1926 .

Weirs are usually applied for fow measurement in small drainage and irrigation canals. Permanent weirs are arranged in crecks or as an arlificial control in rivers with shifting bed. Spillways of exisling dams are also used for overllow measurements. The heokuk Dam across the Mississippi River has 110 spillway sections, each 30 feel wide, the water head is up to 11 feet. In 1924 one section was lested by F.A. Nagler and A. Davis, applying current melers, and also checked on a nodel in the Iowa hydraulic laboratory. The spillway of the 
soir d'une longueur de $34,75 \mathrm{~m}$ fut construit en 1914 sur la riviere Ausable, en aval du barrage Loud (Michigan) pour les essais des lurbines. Le plus grand déversoir provisoire construit ctail celui placé à l'aval du harraze Wilson, sur la rivière Tennessee, el qui fut installé en 1926. If comportait 15 élénents en tôle d'acier à arèLes vives, d'uno longueur unitare de $9,15 \mathrm{~m}$; la iongueu tolale de la crete de ce barrage était de $152 \mathrm{~m}$. Le montage coûla 63000 dollars et le démonlage 5000

\section{ECOULEMENT NON-UNIFORME}

Les luyeres, diaphragmes, coudes et aulres changlements sonl utilisés dans les tuyaux, la vitesse el le déhit ćtanl déterminés par la différence enlre les pressions en amont ef en aval de lobstucle. Un dispositil très couramment utilisé consiste on un passage convergent-divergent a l'intérieur d'un luyau, qui fut inventé par $C$. Herschel, à Holyoke (Massachusetts) en 1887, el appelé « Venturimètre» en l'honneur de G.B. Veniuri, qui fut le premier chercheur à démontrer la perte de charge due a un rétrécissement

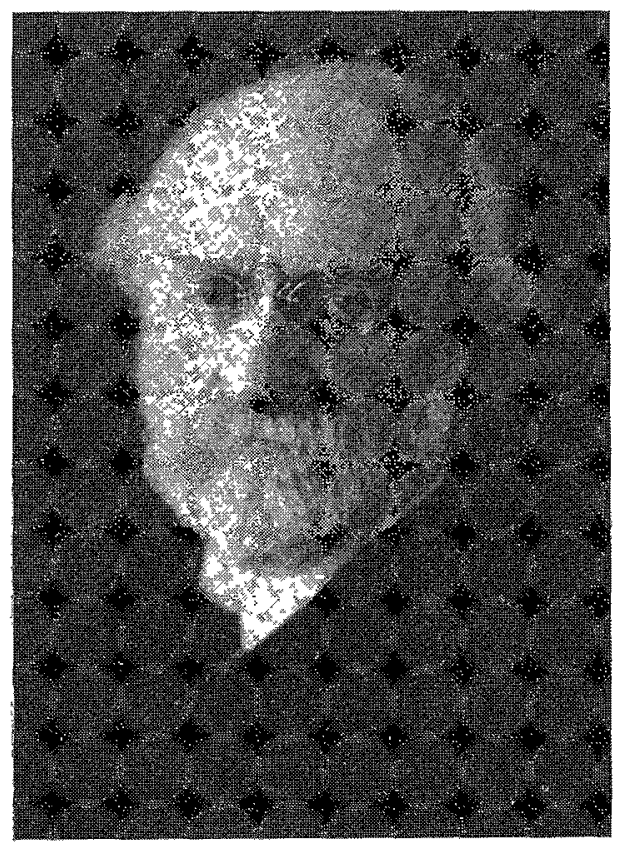

CrRMENS Herscher $(1842-1930)$

(1797). Les Venturimètres se sonl montrés des disposilifs précis el d'ulilisation facile pour l'ean, les raz, l'air et d'autres fluides. On $y$ a ajoute, par la suite, a l'aval du rétrécissement, un diffusetu ayant pour objet de recupérer une partie de l'énergie perdue.

Celle conceplion fut appliquce aux canaux
Vilson Dam on Tennessee River was lested in the same manner by L.G. Puls in 1928.

Weirs also were used for turbine lesting. They were temporarily built in a tailrace of the plant, and sometimes they were quite large and expensive. In 1914 a weir of 114 feet length was built across the Ausable River bolow the Loud Dam, in Michigan, for turbine testing. The largest temporary weir was built below the Vilson Dam in Tennessee River in 1926. It had 15 sections of sharp-edged steel plates, each 30 feet long; the total length of the crest was 500 leet. Construction of that weir took 63,000 : dismounting 5,0008 .

\section{NON-UNIFORM FLOW}

Nozzles, diaphragms, bends and other restrictions are used in pipes. Difference in pressure

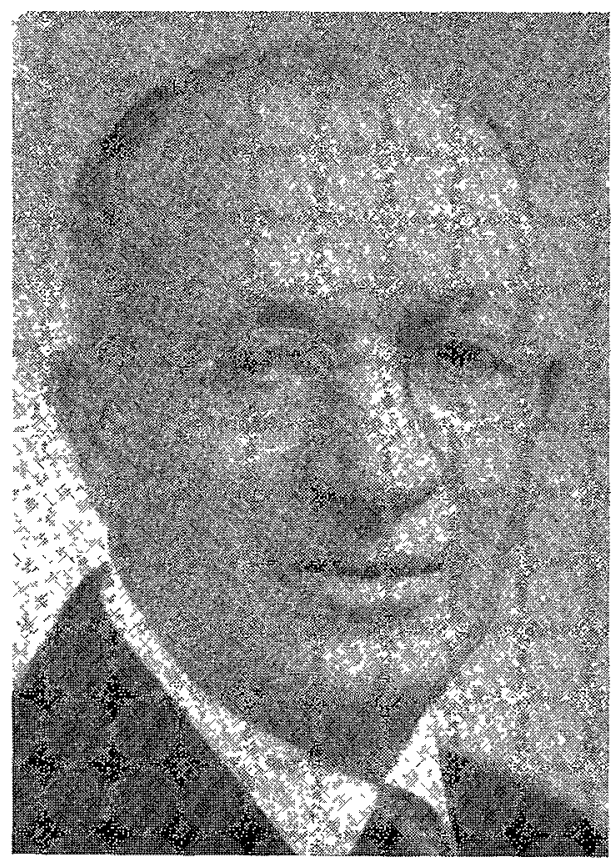

Ralph lazor Parshate. $(1881-1959)$

before and past the obstacle determines the velocity and the discharge. Particularly popular is a throat inside a pipe, invented by $\mathrm{C}$. Herschel in Holyoke, Massachusetts, in 1887, and called renturimeter in honor of G.B. Venturi, who was the first scientist to demonstrate pressure decrease in a constriction in 1797. Venturimeter 
décourerts par V.M. Cone en 1916, sous la forme d'un rétrécissement appelé « camal de Venturi *. Ce canal fut amélioré par R.L. Parshall, qui détermina un econlement critique. Depuis 1929 , on ¿ vu se répandre considérablement l'utilisalion de ce dispositif, connu sous le nom de sanal de Parshall », et remplacant souvent les déversoirs dans les campagnes de mesures. En 1931, un grand canal de Parshall, large de $12,19 \mathrm{~m}$ à la section rétrécie, fut installé dans un canal à La Junta (Californie), pour un débil maximum de $51 \mathrm{~m}^{3} / \mathrm{s}$. D'autres canaux, appelés * canaux à écoulement crilique» ou «canaux à onde stafionnaire $»$, sont également utilisés.

Les difrérences de pression en des poinls apposés dans un coude peurent être utilisées pour la mesure des débits. L'utilisation à cette fin d'un coude réducteur à l'entrée d'une turbine Pelton fut proposée par E.A. Dow en 1922, et le même principe ful appliqué à un coude dans un luyau en 1936 par W.M. Lansford. L'utilisation des coudes pour déterminer les débits étail également connue en Allemagne dès 1870.

Deux méthodes ont été proposées pour la mesure permanente des débits à travers les turbines à réaction:

1. En 1928, J.A. Winter et A.M. Kennedy branchèrent des manomètres sur plusieurs points répartis sur la bâche spirale d'une turbine; ils notèrent les valeurs obtenues au cours des essais, ct choisirent les deux points convenant le mieux à un contrôle permanent;

2. En 1933 , J.A. Peck installa deux piézomètres dans une aube de vamnage de I'avant-distributeur, dont l'un sur le bord face à l'écoulement, et l'autre sur un bord latéral; cetle disposition fut ensuite étalonnèe pendant des essais de rendement de la turbine.

Toutes les méthodes basées sur les différences de pression supposent une certaine perte d'énergie, ce qui constitue un élément défayorable dans les installations de production d'énergie. Le tube d'écoulement de Dall, mis au point par H.E. Dall en 1953, donne lieu à des pertes plus faibles que celles d'un Venturi.

\section{METHODES BASEES SUR LES VITESSES DANS UNE SECTION D'ECOULEMENT}

La mesure des débits basée sur les vitesses dans une section d'ecoulement n'entraine pratiquement aucune perte d'énergie. Il est néces. saire de mesurer les vitesses en plusieurs points, étant donné qu'elles varient à travers la section. Il est particulièrement souhaitable de pouvoir proved to be a convenient and accurate dovice for water, gas, air and other fluids. Diffuser was introduced past throat to regain a part of lost energy.

In 1916 V.M. Cone applied this iden to open channels by introducing a reslriction ealled veluluri flume. R.L. Parshal improred this flume, ascertaining a cribcal flow, and since 1929 this device is widely in use, known as Parshall measuring flume. It often replaces weir in ficld condilions. In 1931 a large Parshall fume, 40 feet wide in the throal, was built in a canal at La Junta, California, for a maximum water discharge of 1,800 cubic feet per second. Other designs of flumes, called critical-flow or stand ing wave flumes, are also used.

Pressure difference in opposile points of bend in a pipe can be applied for discharge measurements. In 1922 F.A. Dow suggested the use of a reducing bend at the inlet 10 an impulse turbine. In 1936 W.M. Lansford adopted this principle to an elbow in a pipe. The use of elbows was known in Germany since 1870.

Two ways were proposed for the permanent measurement of water flow through reaclion turbines: 1) In 1928 J.A. Winter and A.M. Kennedy connected manometers to several points of a scroll case of a turbine and observed them during tests; two best suilable were selected for permanent control. 2) In 1933 J.A. Peck inslalled two piezometers into a stator yane, one al the front edge, another on a side; installation was to be calibrated during effictency tests of the turbine. All methods based on pressure difference presume a cerlain waste of energy, which is undesirable in power developments. The Dall flow tube, designed by H.E. Dall in 1953, requires less losses than venturi tube.

\section{AREA.VELOCITY METHODS}

Discharge measurements by area and velocily methods are almost enlirely free of energy losses.

Velocities of flow must be measured in many points, because they vary across the section. Direcl measurement of the average velocity of the whole section is particularly desirable.

In 1841 a large gagemweel, 16 feet in diameter, was assembled across a supply canal from the Merrimac River in Massachusetts. Seven wheels, each 10 feel wide, were coupled on a horizontal shaft between supporting piers, outfitted with a series of 24 paddles tixed radially around the wheels. Flowing water rotated the immersed paddles, revolutions were counted by a clock-work connected to one end of a shaft. The velocity of water was 2 to $31 / 2$ feel per 
mesurer directement la vilesse moyenne de la section entiere.

Une grande "rone de jaugeage» d'un diametre de $4,87 \mathrm{~m}$, fut installée en 1841 sur toute la largeur d'un canal d'alimentation partant du fleuve Merrimae (Massachuselts); elle était conslituce don ensemble de 7 roues individuelles, chacune ayant $3,05 \mathrm{~m}$ de largeur, accouplées el monlées sur un arbre horizonlal, ce dernier étant supporté par des piles latérales. Chaque roue comportait 24 aubes radiales sur sa périphérie. Les pales immergées élaient déplacées par le courant, provoquant la rotation de la roue, le nombre de tours étanl compté par un mécanisme d'horlogerie relié à l'une des extrémités de l'arbre. La vilesse du courant mesuré dans ce cas était de 0,61 à $1,06 \mathrm{~m} / \mathrm{s}$, ce qui correspondait à un débit de 11,32 à $17 \mathrm{~m}^{3} / \mathrm{s}$. Celte énorme roue de jaugeage était probablement la plus grande qui ait jamais été construite.

La vitesse moyenne dans un canal de section réguhère peut être mesurée an moyen d'un écran hydrométrique fixé sur un chariot léger. Le courant déplace ce chariot sur des rails installés le long du canal. La détermination du débit se fait à partir du lemps nécessaire pour parcourir une distance constante, et de la profondeur d'eau. Ce dispositif fut d'abord essayé sous forme d'un ecran flolleur par G.-A. Hirn, en France, en 1846 , puis introduit en 1905 en Suede pour les essais de turbines, par E. Andersson, où il est connu sous le nom de «Andersson's skärm (écran d'Andersson). Des écrans hydrométriques furent également installes par K. Schmitthenner, à Heidenheim, en 1907, el par E. Reichel, à Berlin, en 1908. Reichel utilisa un tel écran pour des essais sur l'installation de Nottoden, en Norvège, en 1909, et O. Lütschg fit de même en 1910, à l'installation d'Ackersand, en Suisse. V. Mann étudia la précision d'un écran hydrométrique en 1920 , et des améliorations de ce dispositif furent mises au point par W. Wagenbach et E. Kranse en 1932. De nombreux laboratoires, en Europe, utilisent ces écrans pour obtenir des mesures rapides el précises des débits. Cette méthode fut appelée « diaphragm nelhod » par C.R. Weidner, en Amérique, en 1914, mais il fallut altendre l'anné 1954 pour la voir employec dans ce pays, lorsqu'un tel écran ful installe au laboratoire d'hydraulique de Notre Dame (Indiana).

Les mosures dans les canaux déconverts sont nomalement efrectuées en divers points sur plusieurs horizontales ou verticales, et sur des lignes transversales dans les conduiles fermées. II est nécessaire de poursuivre les observalions de vilesse en chaque point pendanl plusieurs minutes, afin de tenix compte des pulsations sccond, the waler discharge 400 to 600 cubic feet per second. This huge gaging wheel was probably the largest water meter ever built.

The average velocity in a regular chamel can be measured by a hydrometric screen attached to a light carriage. Flowing water moves the carriage on rails along the channel. The time needed to travel a constant distance and the depth of water lead to determination of water discharge. First wicd by G. A. Hirn in France in 1846 as a floal with a screen (l'écran flolleur), this device was introduced for turbine lesting by $\mathrm{E}$. Andersson in Sweden in 1905 and is known there as "Andersson's skärm". K. Schmitthenner arranged a hydrometric screen in Heydenheim in 1907, E. Reichel in Berlin in 1908, he

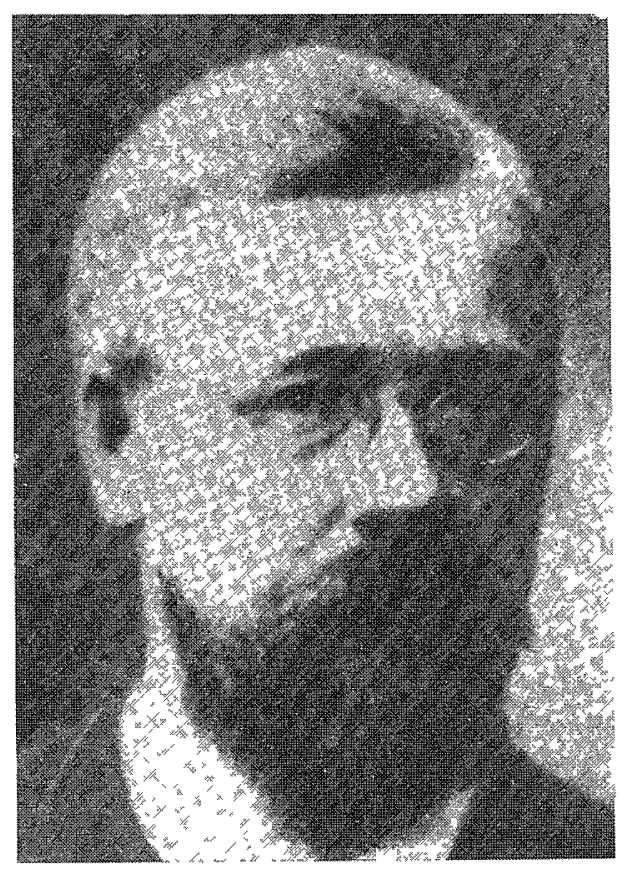

ERTE ANDETSSON (1854-1911)

also applied a screen for tests of the Nottoden plant in Norway in 1909, O. Lutschg tested with a screen the Ackersand plant in Switzerland in 1910. V. Mann investigated the accuracy of a hydrometric sereen in 1920, W. Wagenbach and H. Krause introduced some improvements in 1932. Many European laboratories use hydrometric screen for quick and nccurate discharge measurements. In America this device was described as a diaphragm method by C.R. Weidner in 1914, but was nol applied before 1954 , when it was installed in the Hydraulic laboratory of the University of Nolre Dame, Indiana.

Measurements in open channels are usually performed al difcrent points on series of verticals or horizontals, in closed conduits along traverses. Observation of velocity at every point 
irrégulières de l'écoulement. Les mesures on plusieurs points exigenl done un lemps considérable, dont on ne dispose pas toujouns. L'intégration mécanique est tolérée dans les canaux découverts, de même dans les conduites, mais dans ce dernier cas seulement autour des cercles, el non dans le sens transversal. L'utilisaLion simultanée de plusieurs appareils de mesure et l'enregistremenl automatique de lous les résultats permet un gain de temps. 11 est egalement possible de réduire le nombre de points de mesure pour des mesures approchées ou dans le cas d'un controle continu. Dans ce dernier cas, il est nécessaire d'établir des règles suivant lesquelles la vitesse moyenne se deduil des résultats obtenus en un «point de référence» bien déterminé.

Les tubes de Pitol el les noulinels hydrométriques sont couramment utilisés pour les mesures de ritesse en canaux découverts el en conduites.

\section{PITOTMETRES (TUBES DE PITOT)}

Un tube hydrodynamique permettanl de mesurer la pression due à la vitesse fut inventé par H. Pitot en 1732 , el amélioré successivement par J.-A. Fabre en 1797, Duchemin en 1842, Reichenbach en 1845, H. Darcy en 1856-1885, Ch. Ritter en 1871, I. Amsler en 1880, E. Gieselev on 1885, E.S. Cole en 1896 , J. Danckwerts en 1909, L. Prandl en 1913, Th. Rehbock en 1926. et J. Szily en 1937 .

Le lube de Pitot mesure la vitesse instantanće à son extrémité. II est nécessaire d'efrectuer de nombreuses mesures afin d'éliminer l'influence des pulsations. Le tube de Pitot ne convient pas pour l'intégration, ni par rapport aux distances, ni par rapport au temps. Des pitolmètres intégrateurs proposés par A. Frank en 1895 et W.C. Henning en 1922 ne purent pas être adoplés an raison de leur défaut de précision.

Weinhold fut le premier utilisateur d'un tube de Pitot pour les essais de turbines, en 1872, el H.F. Mills fut le premier Américain à s'cn servir pour des études sur les phénomènes d'écoulement, a Lawrence (Massachuselts), en 1877. Dans cette tude, qui fut reprise par J.R. Freeman par la suite, les entrées des tubes étaient disposées en 16 ou 18 points à lravers la section d'une conduite d'un diamètre de $30,48 \mathrm{~cm}$, les must contimue several minutes due to irregulat pulsation of flow. Measurements in many points need considerable time, which may not be avalable. Mechanical integration is allowed in open chamels, and in pipes around the circles, but not across the pipe. Time can be shortened when a set of instruments is applied simultaneously: and all observations are recorded automatically. Number of points can be reduced for approximate measurements or for continuous control. In that case the rules must be established to compute the average velocity from observations in a selected "index point".

Pitot lubes and current meters are widely used for velocily measmrements in open channels and in pipes.

\section{PITOMETERS (PITOT TUBES)}

A hydrodynamic tube, measuring the velocity head, was invented by H. Pilot in 1732 and

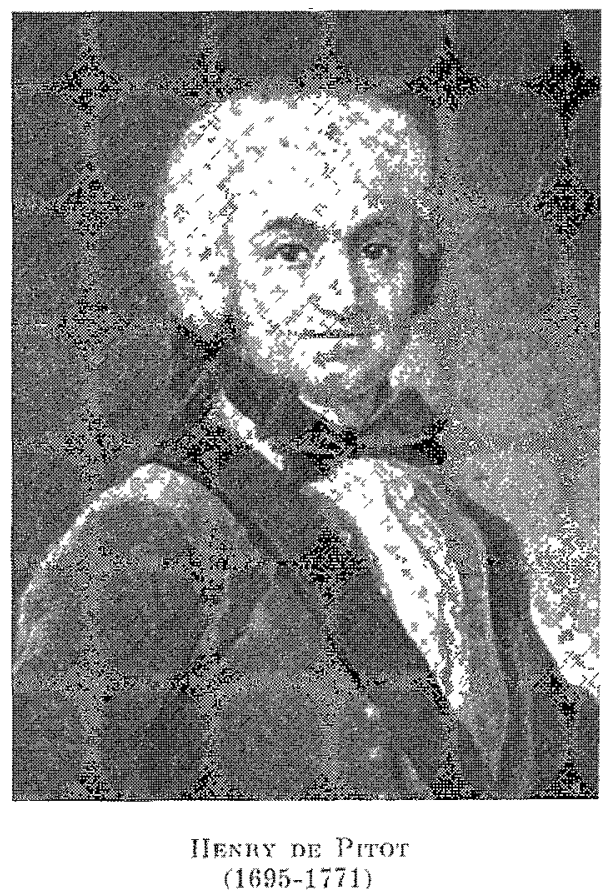

developed by J.A. Fabre in 1797, Duchemin in 1842, Reichenbach in 1845, H. Darcy in 18561885, Ch. Rilter in 1871, J. Amslex in 1880 , E. Gieseler in 1885, E.S. Colc in 1896, J. Danckwerts in 1909, L. Prandl in 1918, Th. Rehbock in 1926, $J$. Szily in 1937.

Pitot tube measures an instant velocity at the point of nozzle. Many readings should he taken in order to eliminate the infuence of pulsation. Pitot tube is not suitable for integration, neither with respect to distance, nor to the lime. Integrating pilometers proposed hy A. Frank in 1895 
hauteurs piézométriques dunt enregistrées simultanément. Nous devons à E.S. Cole la méthode de mesure suivant laquelle on déplace un lube de pitot le long d'unc ligne transversale à travers me conduite, $C e$ chercheur utilisait deux tubes disposés l'un contre l'autre. Le premier pitotmètre à être utilisé pour un contrôle permanent fut celui installé sur la conduite d'eau de Terre Haute (Indiana) en 1896. De nombreux pitotmètres sont utilisés de nos jours. En 1903, Cole mit au point, en collaboration avec $H$. Flad, un photo-pitotmètre enregistrant sur une plaque sensible toutes les fluctuations de la colonne liquide d'un manomètre.

En 1921, A.L. Collins employa un tube de Pitol qu'il foisait glisser à travers la conduite par deux presse-étoupe; un orifice dans la partie avant du tube faisait office de prise dynamique. La méthode "photoflow» fut brevetée par D.W. Proebstel, en 1927. Dans cette méthode, plusieurs tubes de Pitot sont fixés rigidemenl à un cadre aménagé dans une section de mesure et reliés à une lyre manométrique par l'intermédiaire de tubes piézométriques. Les résultals sont enregistrés immédiatement par un appareil photographique el peuvent être évalués après le développement de la plaque. Les tubes de Pitot doivent être étalonnés, pour les mesures précises, en établissant des comparaisons avec d'autres méthodes; cest un procédé assez compliqué.

\section{MOULINETS HYDROMETRIQUES}

Un moulinet hydrométrique est un appareil comportant des aubes ou des coupelles rotatives; c'est l'appareil le plus sûr pour les mesures de vitesse dans les canaux déconverts et les conduites. Il convient pour l'intégration. Tout moulinel doit être étalonné en eau statique.

Il existe deux types principaux de moulinel, les uns comportant une hélice tournant sur un axe dirigé dans le sens de l'écoulement, et les autres comportant des coupelles tournant sur un axe perpendiculaire à l'écoulement et mis en rotation par la différence entre les trainées de deux coupelles opposées.

Le premier appareil à hélice fut introduit par Wollman en 1790 , et amélioré successivement par A. Baungarten en 1837, P. Boileau en 1845 , L.G. Treviranus en 1820-1859, J. Ansler en 1872, A. Fleley en 1875, A.R. Harlacher en 1881, A. Ott depuis 1881, E.E. Haskell en 1886, J. Epper en 1899, S. Hajós en 1903, W. Albrecht en 1908, E.J. Hor en 1921, et H. Dumas en 1948.

Le moulinet à coupelles fut introduit en 1867 and by W.C. Henning in 1922 were rejected as. erroneous.

Pilot tube was applied for turbine testing by Weinhold in 1872. H.F. Mills was the first American to use pitometer for flow studies in Lawrence, Massachusetts, in 1877. His work was continued by J.R. Freeman. The nozzles were located at 16 or 18 points across a 12 -inch pipe. Piezometric levels were recorded simulaneously. E.S. Cole was the promoter of the application of pitometers in the traverse method. He introduced two opposite nozzles. The first pilometer for permanent control was installed in the water main of Terre Haule, Indiana, in 1896. A large number of pitometers are in use now. In 1903, in cooperation with H. Flad, Cole developed a photo-pitometer, which registers on a sensitive plate all fluctuations of the liquid column in a manometer.

In 1921 A.L. Collins applied a tube, sliding across the pipe through two packings. An orifice in the front of the tube served as a nozzle. In 1927 D.W. Proebstel patented the "photoflow" method. Multiple pitot nozzles are rigidly fixed to the frame in a measuring section. Piczometric lubes, connected to them, are located on a common board ("bank"), their readings are recorded by a photo camera instantly and evaluated after processing the plate.

Pitot tubes need calibration for precise measurements. Rating can be performed by comparison with other methods, and is quite complicated.

\section{CURRENT METERS}

A current meler is an instrument with rotating vanes or cups, and is the most reliable for relocity measurements in both open chamels and pipes. It can be successfully applied for integration. Every current meter must be calibrated: the rating is performed in still water.

There are two principal types of current meters, with vanes rotating like a screw about an axis directed toward the flow, or with cups circulating around an axis located across the flow and acting due to the different drag on opposite cups.

The serew type was introduced by $\mathrm{R}$. Woltman in 1790 and improved by A. Baumgarten in 
par D.F. Henry, qui adopta un rotor de l'anémométre de T.R. Robinson. Ce modèle fut ubilisé par Th. G. Ellis en 1871, puis mis au point et breveté par W.C. Price en 1882, de sorte qu'il devint connu surtout sous le nom de « moulinet de Price».

Les tours de l'hélice du moulinet sont transmis par un système électrique el enregistrés. La vitesse d'un courant s'obtient à partir d'une courbe ou d'une loi d'étalonnage. Dans un canal découvert, les moulinets peuvent être utilisés montés sur perche, ou bien montés sur un contrepoids suspendu à un câble. L'attache du moulinet à la perche peul être fixe, coulisser le long de la perche, ou bien elre concue pour permettre de soulever lappareil avec la perche. Les monlinets suspendus à un câble doivent être suffim samment lourds pour pouvoir résister à toute tendance à dériver.

Le modẻle à hélice est sensible au sens du courant. Il est nécessaire de corriger les vitesses des courants obliques mesurées avec un moulinet fixe, afin d'obtenir la projection normale correspondante. Une hélice «auto-composante * mise au point récemment permet de mesurer cette projection directement. L'appareil à coupelles, par contre, ne réagit qu'à la vitesse maximum, quelle qu'en soit la direction; il ne convient done guère aux mesures précises.

Un seul jaugeage du débit d'un cours d'eau naturel exige plusieurs heures de travail, bien qu'il soit possible de gagner énormément de lemps en intégrant. Les essais sur les groupes énergétiques nécessitent l'emploi de jeux de moulinets, le temps disponible pour chaque essai étant limité à environ 10 minutes. Les moulinets sont alors fixés sur un cadre, et l'ensemble ainsi constitué est déplacé à volonté dans une section de la conduite. L'enregistrement attomatique, sur bande de papier, des impulsions fournies par chaque moulinet de l'ensemble, est assuré par un chronographe. Lorsqu'un tel appareil n'est pas disponible, il est nécessaire de prevoir un observateur pour chaque moulinel. Lors des essais effectués à la centrale de Chancy-Pougny, sur le Rhone, en 1926 , par exemple, 9 agents étaient assis l'un à côté de l'autre, observant les résultals de 9 moulinets montés sur un cadre horizonlal.

En 1909, S. Rice ntilisa un cadre comportant 4 moulinets dans un canal de la stalion de pompage de Chicago. B F. Groat exécula, en 1914, des mesures avec 5 appareils sur une perche horizontale, el A. Streiff effectua des essais sur des turbines en utilisant 11 moulinets à la fois. En 1922, H. Thoresen utilisa deux jeux de 14 moulinets en Norvège, el les Suédois firent des essais avec 17 appareils. S. Bitterly en employa 14 pour les essais de la centrale de Faal, en
1837 , P. Boileau in 1845, L.G. Treviranus in 1820-1859, I. Amsler in 1872, A. Fteley in 1875, A.R. Harlacher in 1881, A. Ott since 1881, E.E. Haskell in 1886, J. Epper in 1899, S. Hajós in 1903, W. Albrecht in 1908, E. J. Hof in 1921, H. Dumas in 1948.

The cup type was introduced by D.F. Henry in 1867, who adopted a flier (rotor) of the T.R. Robinson's anemometer. This type was applied by Th. G. Ellis in 1871 and developed and palented by W.G. Price in 1882, therefore is mostly known as a Price meter.

The revolutions of a meter are transmilled electrically and recorded. The velocity of a stream is oblained from a rating curve or equalion. A current meter can be applied in open channel on a rod or on a cable with a weight. It might be fixed on the rod, shifted along the rod or lifted with the rod. Whon suspended on a cable, it should be sufficienlly heavy to withstand the drift.

The sorew type is sensitive to the dircction of the stream. The velocity of oblique currents measured by a fixed meter is to be corrected in order to get the necessary normal projection. A new "component rumer" measures that projection directly. The cup type reacls only to the maximum velocily from any direction, therefore it is not suitable for precise measurements.

Severals hours are necessary to complete one measurement of a discharge of a natural stream. Integration can save considerable time. Series of meters must be available for tests in power plants, where the time is limiled to some 10 minutes for every test. Meters are fixed to a frame, with which they are placed or shifted in a cross section. A chronograph is necessary to record automatically the signals of every meter on a paper tape. If not available, each meter needs its own observer. Thus, in 1926, during tests of the Chancy-Pougny plant on the Rhone River nime observers were sitting in a row while nine meters were in operation, atlached to a horizontal frame.

In 1909 S. Rice used a frame with four melers in a channel of the Chicago pumping plant. In 1914 B.F. Groal applied five meters on a horizontal rod, and A. Streiff tested turbines with 11 meters simultaneously. In $1922 \mathrm{H}$. Thoresen applied two sets of 14 moters in Norway, 17 melers were used in Sweden. In 1927 \$. Bitlerly tested the Faal power plant in Jugoslavia with 14 current meters and in 1930 the Ryburg-Schwörstad in Switzerland wilh $30 \mathrm{me}$ - 
Yougoslavie, en 1927, el 30 pour les essais do l'installation de Ryburg-Sehworstadt (Suisse), qu'il effectua en 1930. D. Thoma installa 20 moulinels dans un canal trapézoỉal de lins tallation de Prombach, on Baviere, en 1929, et 27 dans la rivicre l'lsar, a Aufkirchen. En 1931 , W. Dictrich ulilisa 12 momlinels, constituant deux jeux, pour les mesures qu'il cxécula sur les groupes de Handeck, en Suisse, el enfin, G.F. Merriam el J.M. Mousson inslallirent 27 moulinets dans la centrale de Safe Harbor, sur lo neuve Susquehamna, en 1932. Ces denniers apjarcils comportaionl deax hélices do lormes dirórentes, qui furent utilisćes suecessivement aux mểmes points de mesure afu de permettre la délermi-

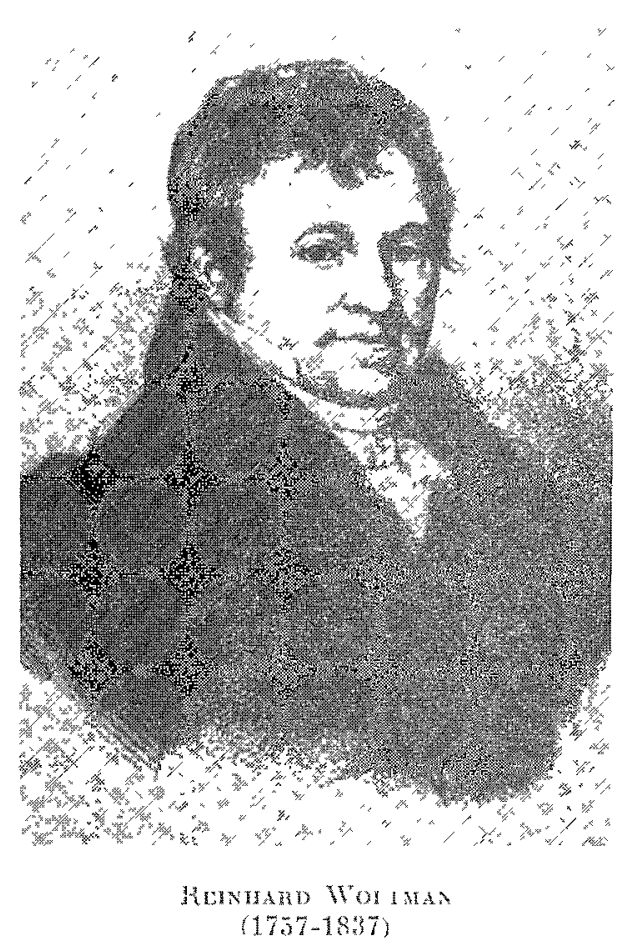

nalion des colpeclions nécessatres pour tenir compte de lobliquité du courant. Lidée d'utilser differents types de monlinet fut suggérée par L.F. Moody en 1914: l'un devait fournir des valeurs trop élevées en écoulement oblique, et l'autre des raleurs trop lables. En 1934, C.E. Streiff et H. Gorber nesurèrent los direchions des flets liquides pendant les essais de la centrale de Wellingen, au moyen de 14 moulinets inclines aux angles correspondants; les projeem lions voulues furent calculées ensuile. En 1945, S. Kolupaila proposa une mélhode de doubles mesures, utilisaul los mêmes moulinets inclinés à des angles définis en régime d'ćcoulement obli(que. L'hclice «alo-composante» ful inventec en 1948, permellanl des mesures précises dans les galeries d'amence des grompes i basse chute. Des essais sulisfaisants onl depuis ćté offectués ters. In 1929 D. Thoma applied 20 moters in a trapezoidal canal of the Pfrombach plant in Bavaria and 27 melers in the Isar River al Auf kirchen. W. Dietrich used 12 meters in two sels during lests of Handeck plant in Swilzerland in 1931. In 1932 C.F. Merriam and J.M. Mousson applied 27 melers in the Safe Harbor plant on the Susquehanna River: The melers were equipped with two types of rumners of different form, they were applied subsequently in the same poinls in order to determine corrections for the oblique flow. 'The idea of use of diflerent types of current meters was suggesled by L.F. Moody in 1914: one type would overregister, another underregister in oblique stream. In

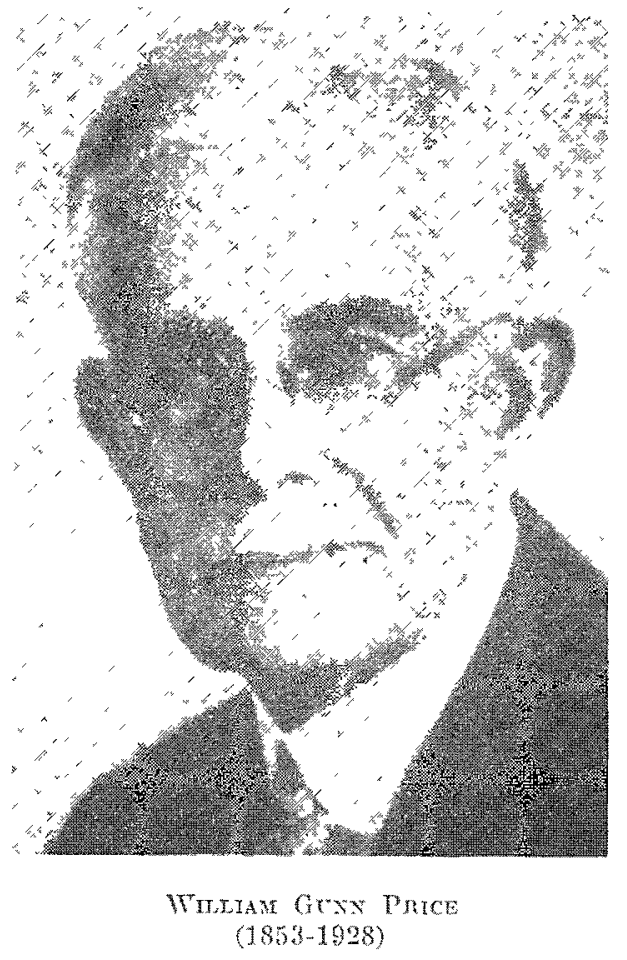

1934 C.E. Strein and H. Gerber measured the directions of stream filaments during the lests of Wetlingen power plant; 14. current meters were tilted at those angles, and the correct projections computed. In $1945 \mathrm{~S}$. Kolupaila proposed a method of double measurements with the same currenl melcrs lilted at certain angles for conditions of oblique currents. In 1948 the "component rumner" was invented, which permils corred measurements in inlels of low-head power plants. H.P. Müller and H. Eschler successfully lested Lurbines with the component runmers.

Multiple current molors have been applied also for infestigulion of velocily distribution in nivers. In 1879 six neters were used in the Mississippi River neat Burlinglon, lowa, by G.A. Marr and A. Mackenzie. In 1899 eleven 
sur des turbines par H.P. Mullex d H. Eschlor, au moyen des hélices nulo-composmontes.

Des moulmets multiples on bgatment éte employés pour étudier la réparthon des vitesses dans les cours d'eau. 6 monlinets frrent cmployés à cetle fin par G.A. Nar el A. Mackenzie. en 1879, dans le Mississippi, pris de Bunlington (Towa). En 1899, 11 monlinets monles sur un seal cable furent utilisés dans la riviere Sain Clair, près de Detroil (Michigan) par L.C. Sabin, et dans la rivione Detron, par M. Bhinchard, cn 1900.

\section{MOULTETS INSTALLES DANS IRS COWDUPRE}

L'ulilisation des moulincis dans les conduiles fermées, surtout celles fonchonnant on charge, est plus délicale. F.P. Steams a electuo des mem sures de débit dans un conduit d'evacualion d'eaux usées, à Boston, en 1833, en introdusant par un tron d'homme un moulinet monté a lextrémilé d'une perche. Le monlinet état mantenu au point voulu de la section de mosure, au moyen d'un dispositif spécial. En 1016, G. Sundby utilisa, en Norvege, deux perches commandés a traycrs des presse-éloune a rotules arliculees; le noulinet éail monlé sur les extrémités jointes de ces perches. La Sociéte Kristinehamn, on Suide, mil au point un presse-éloupe articule convenant pour uno seule pereho; cele-ci so deplacat le long doun sent dinmene, sans sincliner.

En 1908, H. Dufour ulilisa un passage comporlant un joint étanche. Le moulinel s'introduisail a travers ce dispositif dans la conduile en charge, dans laquelle il se denlaçail au houl d'une perche. Aucune vidange préalable de la conduite n'élait nécessare pour installer et relirer les appareils. Des 1912, H. Dufour faisait. loutes ses mesures le long de deux Mgnes lransversales perpendiculaires l'une ì l'aulve; loules deux étaienl inclinécs pour faciliter les mesures. Une méthode analogue ful employéc par $K . A$. Heron, au Colorado, th 1914, ayec, en plus, un comptewours mécanique polís à un cadran a l'exteriem du joint par I'intemedinte d'une limonerie.

De nombreuses dispostions permelant de dóplacer les moulinels a l'merieur de la condule onl éte proposés et essayús. Les uns eherchaient a deplacer l'apparcil aulour du point central de la conduile, pour oblenir des mesures individuelles, ou pour permeltre d'integrer suivant des cercles concentriques. Tous ces disposilifs de rotation et de déplaceubent des nonlinels elaient assez compliques. De plüs, ils n'blatent pas loujours tres surs, car les vibrubons in tonlérieur de la conduite laussaicnl sérieusement melers, mounted on one cable, were applied in the St. Chair River nea Delroit, Michigan, hy L.s. Sabin, and in 1900 in the Delroil River by I. Blanchard.

\section{CURRENT METERS IN PIPES}

More complicaled is lhe operation of current meles in elosed conduits. pavticularly under prossure.

F.P. Stearns measured the flow in a Boston draingse conduil in 1883. Current meter was momnted at the end of a rod and inlrodured through a manhole, I special derice was designed to keep the meler at any point of the section. In $1910 \%$. Sundby nsed in Norway two rods operated through hinged ratves; the jomed ends carticd the current meter. The firm Werlstaden frislinehom in Sxeden improved the hinged ratye for a single rod, which actually was shifled along diameler ondy, wilhout tilling.

In 1908 H. Dnfour constructed a valve with a pucking gasket. The current meter was introJuced through this lock inlo a pipe under pressure and shifled across al the end of a rod. it was nol nesessary to empty the ponstock for inslallation and removal of instruments. After $1912 \mathrm{H}$. Dufom always measured two perpendiculat traverses across the penstock: both were inclined for convenience of operation. In 1914 a similar traverse method was applied hy F.A. Horon in Colorado. A mechanical counler of revolutions was connected by a beam to a dial oulside the gaskel.

Many arrangements were proposed and tested for shifing of current melers inside the pipe. Somo of them provided movement of the meter around the centor of the pipe for sepalate measurements or for inlegration along concentric circles. All devices for rolation and shifling of current melers were rather complicated and not always reliable. Fibralion of the rod inside pipe intertered seriously wilh accuracy of observalions. Fim J.M. Voin suggested the inslallation of permanent lraverses, as supports for shifling mol wilh a moler alluched to il.

Discharge measurements in penslocks of power planls should assure high accuracy and must be made in shot period of lime. The most apropriate solution is the installation of a sorics of current molers fixed al selected points of a cross section. In 192620 meters on two perpendicular iraverses were installed in penm slocks of the roging plant in Bavaria; 25 metors were applied on the same traterses in 1948. In 1929 three traverses were installad in the penslock of the Eiling poxer plant in Bavara, al $60^{\circ}$ one 10 anolher. Fou meters were lixed 
la précision des mesures. La Sociélé J.M. Voith proposa l'installation permanente de traverses à l'intérieur d'une conduite, comme supports pour une perche mobile portant un moulinet.

Les mesures de débit dans les conduites forcés des contrales devraicnt permettre une bonne précision et pouvoir s'effectuer en peu de Lemps. La solulion la plus approprice est d'installer une scrie de moulinets en des points choisis a l'avance dans une section. En 1926, une vingtaine de moulinels montés sur un croisillon i bras porpendiculaires furent installés dans des conduiles forcés de la centrale de röging, en Bavière; on fit de même en 1948, mais cette fois avec 25 moulinets. En 1929, trois traverses furent installées dans la conduite forcée de la centrale d'Eiling, en Bavière, chacune étant inclinée à $60^{\circ}$ par rapport à l'autre. Quatre moulinets furent montés sur chaque rayon, et un au centre, soit 25 appareils en tout. Les impulsions de chaque appareil étaient transmises à un chronographe, qui les enregistrait sur une bande de papier pour chaque essai. Cette méthode esl maintenant très répandue: la nouvelle cdition des normes allemandes «Abnahmeversuche an Wasserturbinen 》 (Essais de réception des turbines hydrauliques), 1957, préconise l'emploi de $13,17,21,25,29$ ou 33 moulinets, suivanl les dimensions de la conduite. On utilise normalement deux traverses perpendiculaires et inclinées. Le plus grand nombre de moulinets jamais utilisés (61) fut installé pour les essais des lurbines de Génissiat, en 1950; chacun des 6 rayons comporlait 9 appareils, un moulinet étail monté au point central, et six autres étaient disposés le long des tirants.

Des moulinets onl souvent été utilisés pour permettre un contrôle permanent du débit. En 1898 , A. Thiem installa un moulinet du type Woltman, équipé d'un système de comptage de tours mécanique, dans une conduite d'eau, à Leipzig. Un prineipe analogue est encore appliqué de nos jours dans plusieurs modèles de compleurs pour les distributions d'eau.

Des moulincts spéciaux de grande talle ont églement été mis au point et ingtallés dans des conduites forcécs à titre permanent. En 1924 , 6 moulinels de ce genre furent installés à la centrale de Walchensee. Leur fonctionnement éait excellent, mais il a malheureusement été ccourté par des avaries mécaniques.

Isa théorie el l'étalonnage des moulinets onl cté améliorés par L.A. Olt; e'est surtout grâce à tui que los possibililés d'emploi de ces appareils précis et sûrs sont devenues si nombreuses. along each radius, and one at the center, 25 meters were employed altogether. Signals given by each meter were transmitted to a chronograph and registered on a paper tape during each test. This method now is widely accepted: the new edition of German standards, "Abnahmerersuche an Wasserturbinen", 1957, suggests $13,17,21,25,29$ and 33 meters for different size of penstocks. Two perpendicular traverses, both inclined, are usually selected. The greatest number of meters, namely 61 , was installed for the tests of the Genissiat power plant in 1950: each of the six radiuses carried nine meters, six meters were atlached to the strenghtening chords and one was at the center.

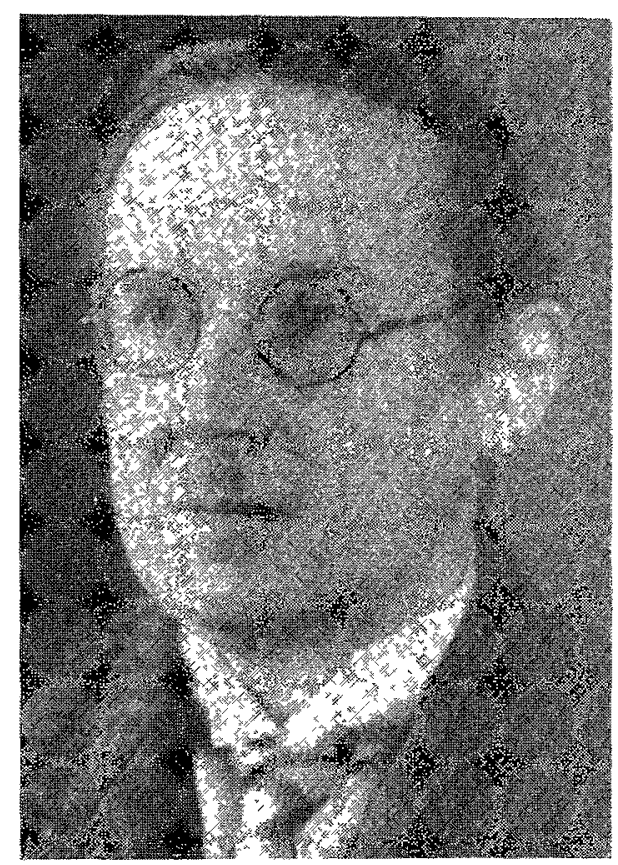

LUDWIG ALBERT OTT $(1883-1946)$

Several times current meters were adapted for a permanent control of the flow. In 1898 A. Thiem installed a current meter of Woltman type in a water main of Leipzig; it was equipped with mechanical transmission of revolutions. Similar principle is still used in many types of water meters for water supply.

Special large size current meters were buill and installed in penstocks for permanent operation. In 1924 six meters were installed in Walchensee power plant. The performance was excellent, however mechanical damage discontinued their operation.

The theory and rating of current melers were advanced by L.A. Ott, who contributed very much to the manifold application of those accurate and reliable instruments. 


\section{JAUGEAGE PAR ECRAN SALE}

Un flotteur constitue le dispositif le plus simple pour les mesures de vitesses. Il peut être employé sous la forme liquide, d'une matière colorante, d'une huile ou d'une solution saline.

En 1920, S.M. Woodward et I.E. Hook effectuèrent des mesures de vitesse, dans une conduite de dragage hydraulique, en utilisant comme flotteurs des écrans salés et colorés, et en observant le temps qu'ils mettaient à parcourir une certaine distance. En 1922, Ch. M. Allen et E.A. Taylor firent des enregistrements électriques du mouvement d'un écran salé au laboratoire d'hydraulique de Worcester. Une bonne précision fut obtenue grâce aux enregistrements précis de la conductivité de l'écran salé. Ce procédé fut mis au point et devint connu sous le nom de «méthode Allen de jaugeage par écran salé $»$. Allen et ses assistants effectuèrent par la suite des essais sur plus de 160 groupes, avec des débits allant jusqu'à $277,5 \mathrm{~m}^{3} / \mathrm{s}$. La méthode fut également essayée dans des galeries de grandes dimensions, tel qu'une galerie, dans l'Etat de Delaware, de $37,8 \mathrm{~km}$ de long et d'un diamètre de $4,57 \mathrm{~m}$. Une demi-tonne de sel fut dissoute pour ces mesures, qui ont donné une précision de $2 \%$.

\section{SALT-VELOCITY METHOD}

A float is the simplest device for velocity measurements. If used in pipes the float can be in liquid form, as dye, ofl, salt solution.

In 1920 S.M. Woodward and I.E. Honk made some velocity tests in a hydraulic dredge conduit, applying salt and dyes for floats. The time necessary to travel a certain distance was observed. In 1922 Ch. M. Allen and E.A. Taylor registered electrically the movement of salt solution in the Worcester hydraulic laboratory. The electric conductivity of a sall wave, precisely recorded, assured high accuracy. The procedure was well developed and known as the Allen salt-velocity method. Over 160 power plants were tested by Allen and his personnel, with a flow as high as 9,800 cubic feet per second. This method was also tried in large tunnels: one tunnel in Delaware was 23,3 miles long, 15 feet in diameter. One half ton of salt was dissolved for measurements, a 2 per cent accuracy was obtained.

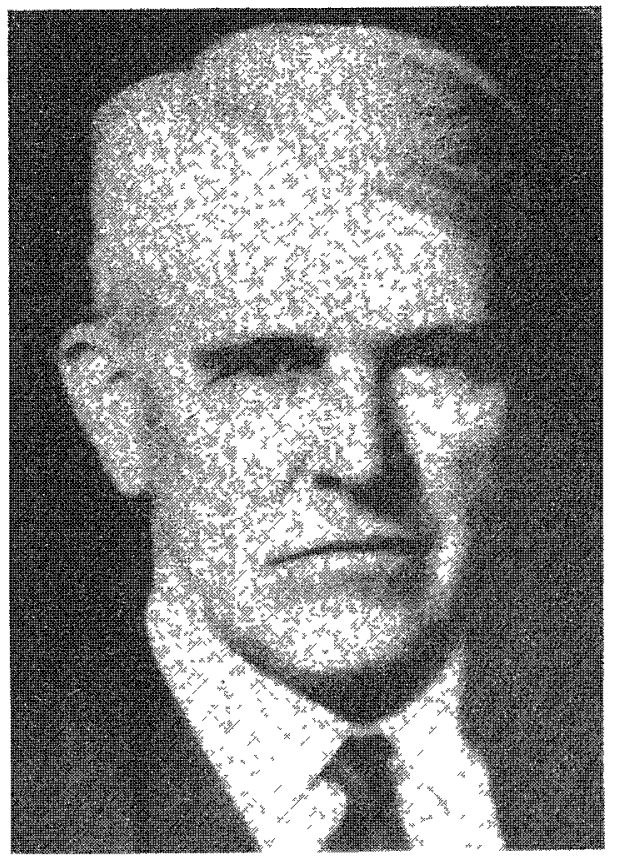

$(1871-1950)$

La méthode Allen fut étudiée en Suède par F. Lindquist, en Allemagne par $\sigma$. Kirschmer, en France par M.A. Mason, en Suisse par P. de Haller, en Italie par E. Scimemi, tant dans les conduites que dans les canaux découverts. Elle fut jugée moins précise que d'autres méthodes.
The Allen method was investigated by F. Lindquist in Sweden, by O. Kirschmer in Germany, by M.A. Mason in France, by P. de Haller in Switzerland, by E. Scimemi in Italy, in pipes as well as in open channels. It was judged as less accurate than other methods. This method is 
Lat móthode Allen est ulilisce do nos jours, et clle a élé mise au point nar $L$. I. Hooper et d'autros spécialistes.

la méthode de jaugeage pat éram sale ful egalement employe pour des mesures sur la naple phrélique par $G$. Thiom, on Allemagne. en 1887 , el par Ch. S. Slichler, on Amérique, en 1902 .

\section{METHODES CHIMIQUES}

Ce fut un physicien francais, Th. Sehloesing, qui, en $186 \%$, eul lidce de mesurer les dobils par une tnolhode chimique, en se basanl sur le prin"ijesurant lequel le rapport des concentrations a'une solution est inversement proportionnel au rapporl des debits. Un ingenieur frangais, Ch. Riller, adapla ce principe anx mesures de lempéralure dans une riviere el dans son afluenl, en 1883. En connaissant l'un des debits, on peut calculer l'aulre a parlir de la varialion des tempéralures. En 1896, Ch. E. Stromeyer essaya, on Angleterre, des méthodes colorimétritues el chimiques de mesure des concentrutions. En 1900 , un ingénieur hollandais, $F$. van llerson, amélion la lechnique des mesures chimiques par litration. Les savants suisses, $\mathrm{A}$. Bouchor ot $\mathrm{R}$. Mellel appliquèrent, pour la premicre lois, la méthode chimique à des meswres sur des groupes énorgetiques en 1909, ainsi qu’à des petiles rivieres, on 1915. Les ingénienrs russes, N.M. Bernadskiti el A.O. Turkov, ulilisèent la nethote avec sucers sur le cours supévieur de la Volga, en 1912. En Amórique, R.D. Johnson employa des malibres coloranles pour des essais par la móthode colorimétrique efrectućs dans une contrale, en 1913. A. Strein ullisa une solulion salée pour lumbines, en 1913, ainsi quo R. Taylor, en 1915. En 1016, B.F. Gron ulilisa la melhode par solution de sel pour les essais de turbine, melhode gu'il nomma schemi-hydromélries, F.A. Nagler verifia des lois de deversoir au moyon le «jaugenges hydro-chimiques $\%$, en 191\%. R.C. Starr ulilisa la même mé.thode à la centrale de Kerekhol, sur la riviere San Joaquin (Chlonvie), en 1921, pour des essais durant lesquels 6 lonnes de sel ordinaire furenl dissous dans $28,4 \mathrm{~m}^{*}$ d'eall potr un essai.

Co ful W.D. Peaslee qui, en 1915, remplaca le premier la litration par des mesures de conduclivile blectrique. Celle mélhode fut nise an point of brevele en Allemagne par L.A. OLt, on 1921. W. Braun l'cudia egalement on 1924. Tne méthode analogue ful introduite en tratie en 1925 par A. Barbagelala el E. Boltani, et brevele en Norvege par J. Aastad el R. Sognen, on 1927. Y. Pisa ful le premior, en 1935, à integrer sill appled and developed by L.J. Hooper and others.

The sall-velocily method was applied for underground water investigations by $\mathrm{G}$. Thiem in Germany in 1887 and by Ch. S. Slichler in America in 1902 .

\section{DILUTION METHODS}

The idea of a dilulion method was originaled by a French physictst Th. Sehloesing in 1863: the ralio of concentration of an ingredient is inversely proportional to the ratio of diseharges. In 1883 a French engineer $C h$. Rilter adopled this idea to temperalure observations in a river and in ils tribulary. When one discharge is known, the other can be computed from the change in lemperatures. In 1800 Ch. F. Stromeyer tested colorimetrical and chemical methods of concentration measurement in England. In 1900 a Duteh engineer $F$. van Iterson improy ed the lechnique of chemical measurement by litration. The Swiss seientists A. Boucher and R. Mellet introduced the chemical method into power plant losting in 1909, and also applied il in small rivers in 1915. The Russian engincers N.M. Bernadskil and A.O. Turkov successfully applied the chemical method on the upper Volga River in 1912. In America R.D. Johnson applied dyes for lesting a power plant by colorimelrical methol in 1913, A. Streiff lested turbines with sall solution in $1913, \mathrm{R}$. Taylor did it in 1915. In 1916 P.F. Groal applied salt dilution method to turbine losts and called this "chemihydrometry". F.A. Nagler checked weir fomulas with "hydromehomical gaugings" in 1913. R.C. Starr used this melhod for tests of Kerckhol power" pant on San Joaquin River in California in 1921: six tons of common salt were dissolved in 7,500 gallons of waler for a lest.

In 1915 W.D. Peaslee was the first to replace tilration by the measurement of electric conductivily. This method was developed and palented in Gemany by L.A. Olt in 1021. W. Braun investigaled this melhod in 1924. Similar mellod was introduced in Inly by $A$. Barbagelata and E. Bollani in 1925, and patenled in Norway by .1. Aaslad and R. Sögnen in 1027. V. Pisa introduced the inlegration of dilution rate instead of the observilion of maximum concenwation in 1935. In $1929 \mathrm{H}$. Neuzil applied fluorescen-natrim for colorimetric measurement of monntain creels will good results. In 1937 B. Esterer investigated this method in Walchensee hydraule laboralory and oblained rery good results with solution as thin as 1 to $4.10^{\circ}$, even 
le taux de dilution maximum au lieu d'observer la concentration maximm. En 1929, H. Neuzil oblint de bons résultats en utilisant de la fluom rescéine-sodium pour des mesures colorimétriques dans les ruisseaux de montagne. En 1937 , $B$. Esterer ćludia cette móthode au Jaboratoire d'hydraulique de Walchensee, ou il obtint de très bons resultats avec une solution d'une dilulion aussi faible que 1 a $4.10^{6}$, résultats encore melleurs que ceux obtenus avec des solutions de sel. La concentration ful évaluce au moyen d'un colorimètre photoélectrique.

La mćthode chimique est encore courante de nos jours; elle a fait l'objet d'une sévie d'arlicles dans La Howille Blanche, en 1950-1954. Divers dissolvants ont été utilisés, et lous ont donné de bons résullals. En 1944 , A.T. Tenz et C.N. Sawyer déterminèrent l'alcalinite de rivicres, dans I'Elal de Wisconsin, en tant qu'indice du débil liquide. En 1956, M. Platzl introduisit lutilisation d'appareils électroniques pour les mesures par dilution dans les rivièes autrichiennes.

Un nowvel aspect des methodes chimiques est l'application des isotopes radioaclifs, comme Lraceurs, aux jaugeages par la méthode chimique. Le premier rapport à ce sujet a été publié par V.F. Hess, en 1943. Cetle possibilite esl du plus haut intérêt.

\section{METHODE DU "COUP DE BELIER"}

Une méthode tout à fait originale pour la mesure des débits dans les conduites fut introduite par N.R. Gibson en 1920, basce sur le phónomène du coup de bélier. Dans celle méthode, on ferme une vanne progressivement à l'extrémité aval de la conduite, el on établit en même temps la courbe des variations de pression en fonction du temps pour un point silué immédiatement a l'amont de la vanne. Une autre méthode, dite «méthode diférentielle», donne des résultats plus précis; elle consiste a noter les variations de pression en deux points dillérents de la conduile, eliminant ainsi certaines sources d'erreurs. Le débil inilial se calcule à partir de l'aire limité par la courbe oblenuc, qui monlre les flucluations de la pression entre les deux points de mesure.

La méthode de Gibson esl très précise. Elle a élé utilisée pour des essais de rendement sur plus de 350 groupes ćnergétiques, dont la plupart sonl installés en Amérique. D. Thoma étudia celte méthode en Allemagne en 1928, el $F$. Salgat en Suisse en 1926. helfer than by sall dilution. A photodedrical colorimeler was used for cvaluation of concentration.

The chemical method is still popular. A series of articles appeared in the magatine "La Houlle Blanche" in 1950-1954. Different solvents were applicd, always suceessfully. In 1944 A.T. Lenz and C.N. Sawyer moasured alcalinily of rivers in Wisconsin as an index of water discharge. In $1956 \mathrm{M}$. Platzl introduced electronic instrumentation inlo dilution method in Anstrian rivers.

A novelty in filution methods is the applicalion of radioactive isolops as tracers. The first paper on this maller was published by V.F. Hess in 1943. This possibility is very promising.

\section{IMPHCT METHODS}

An entrely original method for water measurement in pipes was introduced by N.R. Gibson in 1920. This method is based on the phenomen of waler hammer. A gate at the end of the pipe is gradually closed, a pressure-time diagram is recorded just upstrean from the gate. More

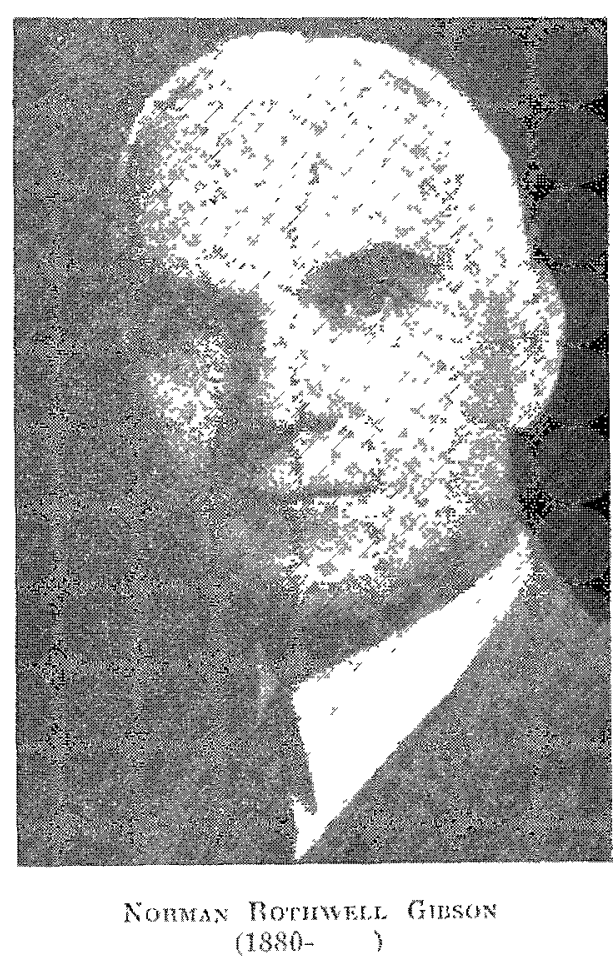

precise is the differential method, when change in pressure in two points of the penslock is recorded, eliminaling some source of errors. The initial discharge is computed from the area under recorded curve, which shows the impulse of the mass of water. 


\section{AUTRES METHODES}

De nombreuses nouvelles méthodes de jaugeağc des débits ont étẻ proposées, limites toutefois dans la plupart des cas aux conduites et aux canaux de section régulière.

Une methode dectromagnétique fut mise au point par A. Kolin à partir de 1936. L'idée d'induire des forces électromagnéticues dans un écoulement fut concue nar E.J. Williams, en 1930. En 1939, W.M. Lansford mesure par induction la déviation d'une plaque magnétique montée sur charnières à l'intérieur d'une conduite. La Société Foxboro, au Massachusetts, fabrique, depuis 1954, un débimètre magnétique dans lequel la tension électrique engendrée par l'écoulement d'un liquide à travers le champ magnétique est détectée par des électrodes introduites dans une section isolée de la conduite, de manière à ne pas perturber l'écoulement.

En 1950, R.C. Swengel proposa la méthode par ultra-sons, bascee sur le passage de sons de haule frécfuence à travers un écoulement. La méthode acoustique fut introduite par A. Fiorenzi en 1931 et appliquée par H.E. Hartig à partir de 1933. On utilise les appareils ultrasoniques pour les mesures de profondeur (sondeur's à ultra-sons) pour les mesures hydrométriques depuis 1925.

La méthode thermométrique pour les essais de turbines ful proposée par A. Poirson en 1914, et appliquéc par $\mathrm{L}$. Barbillon en 1921, et par K.F. Umpfenbach en 1987. Elle se base sur. des observations très exactes des températures de l'eau à l'entrée de la turbine et dans le canal de fuile. G. Willm et P. Campmas, en 1954, transformèrent cette méthode en une méthode thermodynamique basée sur la dilatation thermodynamique de l'eau. Ce procédé consiste à dériver un petit débit constant d'un point en amont de la turbine ef de le faire passer par un détendeur calorimétrique. La pression dans le calorimètre est réduite de manière à ce que la température devienne égale à celle de l'eau dans le canal de fuite, et il suffit alors de mesurer la pression.

Quelques nouvelles idées ont égalenient été appliquées aux mesures de vitesse:

En 1934, C.E. Bentzel mit au point un lube dans lequel l'eau est contrainte de s'écouler par un tube vertical et légèrement divergent; un flotteur ćquilibrant la force de traince indique Ia vitesse. Cette idée est à la base du débitmètre connu sous le nom de «rotametre .0 . Falk fit breveler deux dispositifs délicals comportant un dynamomètre à ressorl en 1950 , et M.C. Boyer mit au point un appareil pour la mesure des faibles vitesses, basé sur l'électrolyse, en 1947;
The Gibson method is very accurate. It was applied for efficiency tests in more than 350 power plants, mostly in America. D. Thoma investigated this method in Germany in 1928. F. Salgat in Switzerland in 1926.

\section{OTHER METHODS}

Many new ideas for water measurement were proposed, mostly limited to pipes and regular channels.

An electromagnetic method was developed by A. Kolin since 1936. The idea of induction of electromagnetic forces in a flow was originated by E.J. Williams in 1930. In 1939 W.M. Lansford measured the deflection of a magnetic plate hinged inside a pipe, by induction. The Foxboro Co. in Massachusetts produces a magnetic flow meter since 1954. Electric tension generated by the flow of a liquid through the magnetic field is detected by electrodes introduced inside an insulated link of the pipe and not interfering with the flow.

In 1950 R.C. Swengel proposed the ultrasonic method based on the high-frequency sound transition across a current. The acoustic method was introduced by A. Fiorenzi in 1931 and applied by H.E. Hartig since 1933. Ultrasonic devices for depth measurements, called fathometers, are in use in hydrometric work since 1925.

The thermometric method of turbine testing was introduced by A. Poirson in 1914, applied by L. Barbillon in 1921 and K.J. Umpfenbach in 1937. It is based on a very exact observation of water temperature before entering the turbine and in the tailrace. In $1954 \mathrm{G}$. Willm and P. Campmas modified this method into thermodynamic, based on the thermodynamic expansion of water. A small steady stream of water is diverted from a point upstream from the turbine through a throttling calorimeter. The pressure in the calorimeter is reduced so that the temperature becomes equal to the tailrace, and pressure only is to be measured.

Some new ideas are applied to relocity measurements.

In 1934 C.E. Bentzel developed a new tube: water is forced to flow through a vertical and 
il y apporta des améliorations en 1953 . Le même principe avait dejá élé employé par W.S.I. Cleverdon en 1916. Celle méthode a recemment été étudiée par W.E. Renz, qui a trouvé que les réactions chimiques en jen n'élatent pas suffisamment sûres pour permetre des résultats cohérents. En 1950, A.T. Ippen employa une cellule manométrique électronique pour ćludier les fluctuations de débit. Avec cette mélhode, la hauleur dynamique dans un tube de pitol esl convertie en unc pression qui est alors transmise à une cellule manométrique. La déformaLion de la membrane de la cellule est amplifée et enregistrée électroniquement.

Un anemomótre à fil chaud, basé sur une perte de la chaleur de convection fournie par un courant électrique est encore une idée nouvelle et intéressante. Ce dispositif, inventé par L. Weher en 1894, et mis au point pour les mesures dans l'air en écoulement par L.V. King, fut appliqué aux écoulements d'eau par G. Gangadharan en 1931, et par T. Ch. Sen en 1933. De meilleurs résultats ont été oblenus à l'Tnstitui de Recherches Hydrauliques d'Iowa en adaptant des techniques électroniques modernes: S.C. Ling réalisa un anémométre à film chaud en 1955 , et Ph. G. Hubbard mit au point un anémomitre à fil chaud utilisant une température constante et relativement basse, et un couranl électrique alternatif. Ces appareils délicats sont seulement utilisés dans los laboratoires.

\section{ESSAIS COMPARATIFS}

Cette courte revue se termine par une liste des plus importants essais comparalifs réalisés jusqu'à présent:

1012. - Mesures exécutées par O. LüLchg à la centrale de Lonza, à Ackersand (Suisse), comparant les résultats obtenus avec des déversoirs, des moulinels. un écran hydrométrique, et la méthode par dilution saline.

1922. - Expériences réalisées par O. Lütschg à la centrale d'Amsteg (Suisse), dans lesquelles il a comparé les résultals oblenus avec un déversoir, des moulinets, la méthode par dilution saline, avec les résultats de mesures volumétriques.

1929. - Essais comparatifs exéculés par 0 . Kirschmer dans une conduile forcée de diamètre variant de 1,85 à $2,25 \mathrm{~m}$, à la centrale de Walchensce (Baviere). Dans ces essais, les diverses mesures furent exécutées en même temps par des spécialistes compétents, au moyen de slightly divergent tube, a float balancing the drag force serves as an index of velocity. This idea was developed into a rotameter, one lype of water meters. O. Fall palented two delicale devices wilh a spring dynanometer in 1950. An instrument for low velocity measurements hased on an electrolylic action was developed by M.C. Boyer in 1947 and improved in 1953. The same principle was applied by W.S.L. Cleverdon in 1916. Recenlly W.E. Renz investigaled this melhod and found that chemical reactions involved were unreliable for consistent results. In 1950 A.T. Ippen applied electronic pressure cell to investigation of flow fluctuations. The dynamic head in a pilot lube is converted into pressure which is transmilted to a pressure cell. The deflection of the diaphragm is amplified and recorded electronically.

A new and promising device for flow invesligation is a hol-wire anemomeler, hased on a loss of conveclive heat supplied by electric current. Invented by L. Weber in 1894, technically developed for air streams by L.V. King, this mothod was applied in water by $G$. Gangadharan in 1931 and $T$. Ch. Sen in 1933. Modern electronic techniques were adapted with better results in the Iowa Institute for Hydraulic Research, where S.C. Ling constructed a hot-film anomometer in 1955 and Ph. G. Hubbard developed a new hot-wire anemometer, based on a constant and relatively low temperature and an alternat. ing electric current, in 1957. These delicale instruments are in use in laboralories only.

\section{COMPARATIVE TESTS}

A list of most significant comparative tests concludes this short review.

In 1912 O. Lütschg performed measurements in the Lonza planl al Ackersand in Switzerland. Weir, current meters, hydrometric screen and salt dilution method were compared.

In 1922 o. Lutschg conducted experiments at the Amsles power plant in Swilzorland. Weir, current meters and salt dilution melhod were compared with volumetric measuremenl.

In 1929 O. Kirschmer led comparative experiments in a penstock of the Walchensee power 
moulinels, pitolmolles, écrans sales, et la mélhode de Gibson.

19,0. - Essais par O. Kirschmer et B. Esterer dans le canal du laboratoire d'hydraulique de Walchensee (longueur $250 \mathrm{~m}$, largeur $2,5 \mathrm{~m}$, profondeur $2,0 \mathrm{~m}$ ), Dans ces essais, on a vérifié des moulinels de deux modèles, un déversoir, les mélhodes par écran salé el par dilution saline, au moyen de mesures volumelriques.

1957. - Essais comparatifs organisés par F.A.L. Winternity dans une conduite forcese d'un diamolre de $1 \mathrm{~m}$, à la centrale hydroćlcclrique de Kinlochleven (Ecosse). Comparaison entre des moulinets (13) pelils moulinels de laboratoire), des pilolmitres, les méthodes par écran sale el par dilution saline. Le chronographe classique fut remplace par des compte-tours électromagnétiques el des enregistrements pholographiques.

1958. - Comparaison entre sept mélhodes différentes à la centrale de Finlay (Ecosse): Dilution saline, écran salé, moulinels, pilotmelres, déversoir, méthode hermodynamique et méthode de Gibson. plant in Bavaria, 73 to 88 inches in diameler. Current meters, pitometers, salt-velocily and the Gibson methods wero applied parallelly by competent experts.

In 1930 O. Kirschmer and B. Esterer perform. ed experiments in the Walchensee hydraulic laboratory, in its canal, 820 feet long, 8 feet wide and 6 feet deep. Current meters of both types, weir, salt-velocily and salt-dilution methods were checked by volumetric measurements.

In 1957 F.A.L. Winternitz organized compar ative lests in a 40-inch penstock of the KinTochleven hydroelectric station in Scotland. Current meters (13 small laboratory meters), pitometers, salt-velocily and salt-dilution methods were compared. Electromagnetic counlers of revolutions with pholographic recording were applied instead of the conventional chronograph.

In 1958 seven different methods were compared in the Finlay power plant in Scotland: saltdilution, salt-velocity, current meters, pitometers, weir, thermodynamic and the Gibson methods were applied.

\section{BIBLIOGRAPHIE}

\section{VOLUMETRIC MLASULEMFNTS}

M. MacDovate and $14, \mathrm{~L}$. luust. The measurement of the discharge of the vile through the stwees of the Assuan dan. Minutes ol lroteedings of the Instation of Civel Lryineers 312 (1921), pp. 228-301, London,

\section{ORIFICES}

F. Bumber. Fin neues Vorfalren zut Wassemessung. Zeitschril des loweins Deutseher lngeneure, $36(1892)$ No, 51, pr. 1493-119k, Berlin.

II. L. Luns and D.A. W. TAT. The measmement of the discharge of the Nile through the sluices ol the Assuan dam. Minutes of loveedings of the Institution of civit Engheres, 219 (1924), pu. 113-180, London,

\section{Wills}

4. H. Fanchs Lowell hytruthe experiments. Boston,

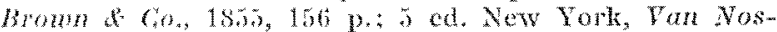
lrand, $1000,280 \mathrm{p}$.

H. Bazn. Faperienees nouvelles sur l'conlement en deversoir. Pants, fhnod, $1898,200 \mathrm{p}$.

7. Thouson. On experiments on the measurement of water by triangulav notehes in weir boards, Report 28th Heving of he brtish Astociation of the Advancemont of Sithnes. is (1858), py, 181-185, London.

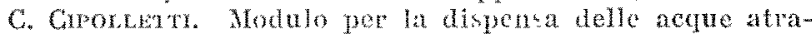

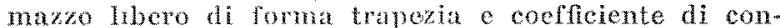
fratone costante Nhlano, Hoepti, $1886,88 \mathrm{p}$.

O. W. P. Srov, A new fun of weir noteh. Transations of the Nebraska Engineering Society, 1 (1807), No. 1 , pu, 13-16, Lincoln, Nebr.

A. Sravs und $\mathrm{K}$. vow Saxpex. Dex lateiswnde Uaberall und seine Abarten. Nunchen, Odenbourg, $1926,39 \mathrm{p}$.

F. A. Nagler and A. Davis. Fxperiments on dischare over spillways and models, Teokul Dam. Transactions of the American society of Civil Fngineers, 94 (1930), pp. 777-844, New York.

L. B. Fuan. Results of effeiency tests at Wison dam. Power Plant Engineering, 31 (1027), No, 15, po. 832. 835, Chicago.

\section{NON-UNTFORM FLOW}

C. Huxsaner. The Venturi water meter, Transactions of the Americh Socichy of Civit Engingers, 17 (1887), pv. 228-258, New York.

C. Hexscher. A farewell word on the Venturi meter. Fngzheering News-Record, $102(1929)$, No 16, pp. 636687, Now York.

V. M. Coxe. The Venturi fume. Tonrnat of Agrichllumel Research, $9(1917)$, No. $t$, pp. 115-129, Washington.

R. H. Parsfald. The improved Venturi flume Transacfions of the American Soctety of Civit Engineers, 89 (1926), pp. 841-951, New Yovk.

1. A. Wixtex, Improved type of flow meter for hydranle turbines. Transactions of the Amertan Soctety of Cuvil Engineers, 99 (1934), pp. 847-872, New Tolk.

\section{AREA-VELOCTTY MLTHODS}

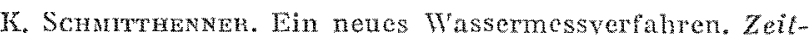


schill des Vercins Deutscher Ingenieure, 51 (1907), No. 16, pp. 627-631, Berlin.

V. Mase. Dentrag zur henntms der Wassernessung mittels Messchirms. Wunchen und Berlm, oldenbourg, $1920,3 a \mathrm{p}$.

\section{PITOMETERS}

H. Purot, Descruption d'une machine pour mesurer des caux courantes, Memotres de lacadernte Rogale tess Sciences (1732), 12 nov, pp. 303-376, Paxis.

E.S. Con.E. Water waste and its detection. Journal of the Western Socretly of Engineers, $7(1902)$, No, 6 , pp. 574-595, Chicago.

D.W. Promistel. Measuring water flow in conduits. Electrical Worla, $83(1925)$, No, $14, \mathrm{pp}, 711-712$, New York.

\section{CLRRENT METERS}

R. Wonmax. Thentic und Gebrach des hydrometrischen Flagels. Hamburg, Hoflmann, 1790.

D. F. HENRy. Flow of watex in rivers und canals. Detroit, Graham, $1873,86 \mathrm{p}$.

W. G. Prilce. Gauging of streams. Journal of the Weslern Soclety of Engineers, 3 (1898), No. 3, pp. 1025-1038, Chicago.

J. M. Moussox. Water gaging for low-head units of high capncity, Transacions of the American Society of Mechanical Engnneers, 57 (1935), pp. 303-316, New York.

s. Folupalla. Use of current melers in turbulent and divergent channels. International Association of SeienIific Hydrology, General Assembly of Toronto, 1957 , 1 vol., pp. 437-144, Gentbrugge, 1058.

A. MackeNgre. Report on current meter observations in the Mississippi River, nen Burlington, Iowa. Washington, 1884, $80 \mathrm{p}$.

\section{CURRENT METERS IN PIPES}

H. Duforr. Flügel-Wassermessungen in Druekrohrleitungen. Schwetzerische Bauzeilung, 84 (1924), No. *, pp. $39-49, Z$ urich.

L. A. Orr. Wassermessungen bei Wasserkraftanlagen. W'asserkraft,fahbueh, 1 (1024), pp. 273-282, Munelren.

\section{SALT-YELOCITY METHOD}

Ch. M. Arrzx and E. A. TAyrom. The salt velocily method of water measurement. Transactons of the Ameriran Society of Mechunical Engineers, 45 (1923), pp. 28,3-341, New York

M. A. Masow, Contribution à l'étude de la mesure des débits d'eau par la methode Allen. Revue Générale de IPlydralique, 5 (1989), No. 28, pp. 177-194; No. 29. pp. 242-259, Paris.

\section{DILUTION METHODS}

Th. Scmoesixf. Nonvelle mathode pour jauger' les lluides Comples rendus hehlomalnures des séanees de T'Aculthie des Siences, 57 (1863), 2 sem., No. 3, pp. 164-166. Paris.

F. Yan Ircrson. Neuwe methode ter bepaling ran de waterhocedhed selexerd don centrifugalpompen. De Ingenieut, $15(1000)$, No, 0, p. 130, s'gravenhage
R. Mexter. Application de latitation des chlorures au

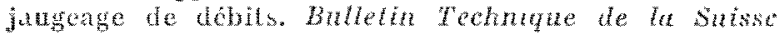
Romande, $36(1910), \mathrm{No}, 11$, pp. 125-128, Lausane.

W, D. Prabsix. The sathe methed of water flow measurement. Jonnal of Electricity, Power and Gus, is (1915), No. 8, 1p. 130-135: No. 9. pu. 148-149, Sin Francisco.

\section{MPACT MLTHOD}

N.R. Guson. The Gilson methed and apparalus for measurng the flow of whter in closed conduits. Transartions of the American Somety of Mechanioul Fingineas, 45 (19231, pp. 343-376, Now York

N.R. Grssox. Fxperrence in the use of the Gibson method of water measurement of effeieney tests of hydraulic turbine. Journal of Basic Engineering, Transachions of the Anerican Society of Mechenical Fingineers, 81 (1959), D, No 4, dee., pp. $456-487$, New Tonk.

\section{OTHER METHODS}

A. Kons. Electromagneti felometry, 1: A method for the determination of fluid velocity distribution in time and space. Joumal of Applied Physies, 15 (1944), No. 2, pp. 150-161, Lancaster, Pa.

R. C. Swexdex and W.B. Hess. Development of the ultrasonic method for measurement of fluid flow. Procecdings of the Sixh Hydraulics Conference, 1955, pp. 61-72, Iowa City, 1956 .

P.G. HubBand. Opernting manual for the Imm hot-wire and hot-film anemometers. State Unibersing of loukd, Bulletin 37, Towa City, 1957, 31 p.

L. Barmilon et A. Porrsox: Mélhode hermométrique pour fa mestre du rendement des furbines hydrat liques. Revue Générale d'Electricha, 10 (1921), No. 21 p. 780 , Paris.

(․ WhLlM et P. Campras. Mesure du rendement des turbines hydrauliques par la methode thernometrique Poirson. La Houlle Blanche, 9 (1951), No. 4, pp. 449460 : No. 5, pp. 590-607, Grenohle.

\section{COMPARATIVE TESTS}

L. W. Commo R. Mrum at O. Lursche Jaugeages par titrations et essals comparatils effectues a a liusine hydroéletrique de l'Achersand. Communications du Service de I'Hthlographie rationale, No. 1, Beme, 1913. $24 \mathrm{p}$

F. Kuntacust. Fssais eomparaters tans les canoux de

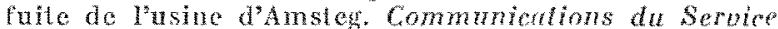
des Fana, No, 18, Berne, 1926, $107 \mathrm{p}$.

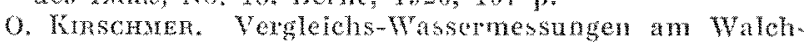

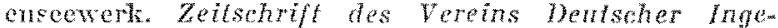
niene, 74 (1930), No. 17. pp, $31-28$, Bethin.

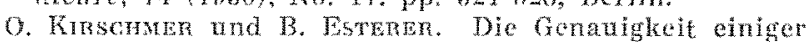

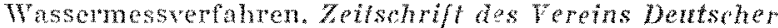
Ingeniente, 74 (1930), No. 44, pp. 1409-1504, Berlin.

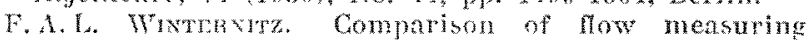
lechinues at Tinlocheven hydrodectic station. Wechancal Fngineping Rewearh haboratory, Fhäl

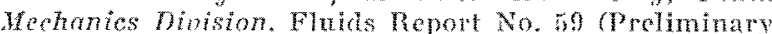
165e) and No, 65 (Final tasts). Khbride, Glasgow, 1957 and 1958,53 and $60 \mathrm{p}$.
Cette liste est très courte. Cne bibliographie plus étendue compilée par lautcur, est en cours de publication par ]'Université de Notre Dame: dle est subyentionnée par la Fondation Scientifque Nationale des Etats-Unis.
This bibliography is very short. The author complied a large Bibliography of lyydrometry, which is now being published by the Cniversity of Notre Dame with a grant from the National Science Foundation of the rnited States. 